\section{Side effects of verapamil in infants}

\author{
DOROTHY RADFORD
}

The Prince Charles Hospital, Brisbane, Australia

SUMMARY Two infants with supraventricular tachycardia were given intravenous verapamil and subsequently suffered life threatening bradycardia and hypotension. As there were no predisposing factors, direct drug action is implicated and other reports of the adverse effects of verapamil are noted. Supraventricular tachycardia in neonates and young infants may be safely treated with digoxin and cardioversion, and intravenous verapamil should be avoided.

Verapamil is a useful drug for treating supraventricular tachycardia in adults. ${ }^{1}$ There have been enthusiastic reports of its use in infants and children $^{2-4}$ and it has been suggested that verapamil is the best drug for paroxysmal supraventricular tachycardia in infants who have no underlying heart disease. ${ }^{5}$ We report 2 infants who suffered haemodynamic problems which were directly related to the drug and suggest that verapamil should be used with caution.

\section{Case reports}

Case 1. A normal 3 week old infant began to refuse feeds and to vomit. On examination he weighed $3.5 \mathrm{~kg}$; was afebrile and mildly dehydrated, with cool mottled skin; and had a heart rate of 260 per minute, a respiratory rate of 76 per minute, normal heart sounds, and no hepatosplenomegaly.

His electrocardiogram (Fig. 1) showed supraventricular tachycardia and on chest $x$-ray examination his heart size was at the upper limit of normal. Oxygen treatment improved his skin colour. To correct the supraventricular tachycardia intravenous verapamil $0.4 \mathrm{mg}$ was given with careful ECG monitoring. A sinus rhythm of 150 per minute resulted, but then asystole occurred. He was resuscitated with intubation, ventilation, external cardiac massage, adrenaline, and sodium bicarbonate.

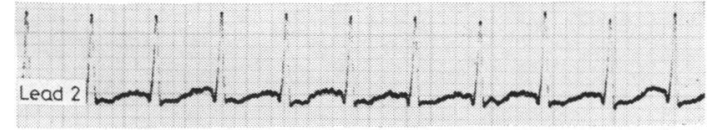

Fig. 1 Electrocardiogram (case 1). Supraventricular tachycardia at 290 beats per minute. (Paper speed-25 $\mathrm{mm}$ per second).
After 5 to 10 minutes he had spontaneous respirations, but further supraventricular tachycardia occurred. $\mathrm{He}$ was given intravenous digoxin $50 \mu \mathrm{g}$, dexamethasone, frusemide, and intramuscular phenobarbitone. A first attempt at cardioversion using 5 joules was unsuccessful but the second shock of 10 joules resulted in sinus rhythm at 160 per minute. The infant recovered and was discharged on a maintenance dose of digoxin. There have been no further problems.

Case 2. A normal baby girl aged 6 weeks began to vomit, refuse breast feeds, and developed rapid respirations. She was admitted to hospital after 3 days. On examination she weighed $3.9 \mathrm{~kg}$ and was afebrile. She looked ill, with central cyanosis, poor skin perfusion, nasal flaring, a respiratory rate of 80 per minute, and a heart rate of 250 per minute. The liver and spleen were palpable $6 \mathrm{~cm}$ and $2 \mathrm{~cm}$ respectively below the costal margin. A gallop rhythm and scattered fine crepitations were audible.

Her electrocardiogram (Fig. 2) showed supraventricular tachycardia. On chest $x$-ray examination the heart was enlarged and there were increased interstitial lung markings with patchy diffuse opacities in the lower zones. The white cell count was $27400 / \mathrm{mm}^{3}\left(27.4 \times 10^{9} / 1\right)$, with $38 \%$ lymphocytes and $56 \%$ neutrophils showing toxic granulation. The results of blood gas analysis showed pH 6.91,

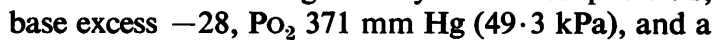
$\mathrm{PCO}_{2} 18 \mathrm{~mm} \mathrm{Hg}(2 \cdot 4 \mathrm{kPa})$. Her serum electrolyte concentrations, including calcium, were normal.

Paroxysmal supraventricular tachycardia associated with sepsis was diagnosed. Treatment with oxygen, intravenous sodium bicarbonate, and intramuscular digoxin $100 \mu \mathrm{g}$ was given. Specimens were taken for bacteriological culture before beginning treatment with ampicillin and gentamicin. Subsequently, all cultures and viral studies were negative. The infant's clinical condition improved

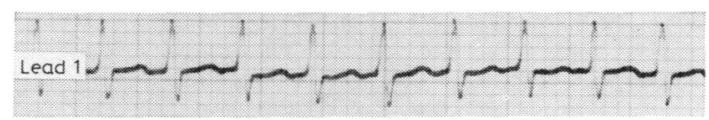

Fig. 2 Electrocardiogram (case 2). Supraventricular tachycardia at 270 beats per minute. (Paper speed-25 $\mathrm{mm}$ per second). 
but supraventricular tachycardia continued for a further 6 hours. Intravenous verapamil $0.4 \mathrm{mg}$ was given. She reverted to sinus rhythm but then developed profound bradycardia and collapse requiring ventilation and external cardiac massage. Intravenous isoprenaline was given to correct the bradycardia but this caused a resumption of supraventricular tachycardia at 250 beats per minute. Cardioversion was undertaken using 5 joules and resulted in a return to sinus rhythm. One further bout of tachycardia also responded to cardioversion. The next day the infant had a fit, was found to be hypocalcaemic, and was treated with calcium gluconate and diazepam. There were no further problems. She was asymptomatic on a maintenance dose of digoxin for 1 year and is now a normal 3 year old child.

\section{Discussion}

Reports of treatment with intravenous verapamil in infants have documented complications and provided explanations for these. Cardiac arrests, severe hypotensive episodes, and heart block have been related to overdosage ${ }^{35}$ or to the prior use of beta-blocking treatment. ${ }^{46}$ Porter et $^{\mathrm{al}} \mathrm{l}^{7}$ found that verapamil was effective only in cases of supraventricular tachycardia due to re-entrant mechanisms. Two of their infants with junctional ectopic tachycardia became severely hypotensive when verapamil failed to stop the arrhythmia. Low serum calcium was implicated in the cardiac arrest of a cyanotic infant with acid base imbalance. ${ }^{6}$

The dose of verapamil given to the two infants in this report was the recommended safe intravenous dose of $0.1 \mathrm{mg} / \mathrm{kg}$, given over 30 seconds. $^{7}$ Neither infant had had treatment with beta blocking drugs and the single dose of digoxin given to case 2 was unlikely to cause toxicity. The electrocardiograms did not show junctional ectopic tachycardia, but atrial ectopic tachycardia is not excluded without an intracardiac electrophysiological study. ${ }^{7}$ Case 2 was severely acidotic and had a normal serum calcium concentration on admission but her subsequent symptomatic hypocalcaemia probably resulted from the use of sodium bicarbonate. Although verapamil impedes calcium transport across the cell membrane, there is little evidence that hypocalcaemia affects this action. The problems that occurred were probably caused by exaggerated drug action producing severe atrioventricular block, direct reduction in myocardial contractility, and vasodilatation.

Neonates and young infants given intravenous verapamil seem to be susceptible to problems, and the 2 cases reported here had serious complications. Sudden hypotension and near fatal cardiac arrest after treatment with intravenous verapamil also occurred in 3 neonates in Vellore (I Sukumar, personal communication). One neonate in Israel required 2 hours of resuscitation and inotropic

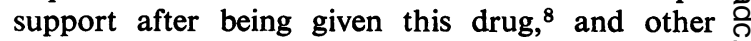
reported complications have also been severe. ${ }^{3-7}$ in Treatment with verapamil should be avoided in neonates and very young infants, and if digoxin does not stop supraventricular tachycardia, cardioversion is safer.

\section{References}

1 Krikler D. Verapamil in cardiology. Eur J Cardiol 1974; 2: 3-10.

2 Bein G, Wolf D. Therapic supraventrikularer paroxysmaler tachykardien bei neugeborenen mit verapamil. Padiatrische Praxis 1973; 12: 405-10.

3 Musto B, Greco R, Calabrò R, Marsico F. Trattamento acuto della tachicardia parossistica sopraventricolare e del flutter con verapamil, nell 'etá' pediatrica. G Ital Cardiol 1979; 9: 368-73.

4 Shahar E, Barzilay Z, Frand M. Verapamil in the treatment of paroxysmal supraventricular tachycardia in infants and children. J Pediatr 1981; 98: 323-6.

5 Soler-Soler J, Sagristá-Sauleda J, Cabrera A, et al. Effect of verapamil in infants with paroxysmal supraventricular tachycardia. Circulation 1979; 59: 876-9.

6 Greco R, Musto B, Arienzo V, Alborino A, Garofalo S, Marsico F. Treatment of paroxysmal supraventricular tachycardia in infancy with digitalis, adenosine-5triphosphate, and verapamil: a comparative study. Circulation 1982; 66: 504-8.

7 Porter CJ, Gillette PC, Garson A, Hesslein PS, Karpawich PP, McNamara DG. Effects of verapamil on supraventricular tachycardia in children. Am $J$ Cardiol 1981; 48: 487-91.

8 Abinader EG, Berger A. Letter: Verapamil and PSVT. Circulation 1979; 60: 1198-9.

Correspondence to Dr D J Radford, The Prince Charles $\mathrm{N}$ Hospital, Rode Road, Chermside, Brisbane 4032, Australia.

Received 4 January 1983 